\title{
Crassostrea Ariakensis In Chesapeake Bay: Growth, Disease And Mortality In Shallow Subtidal Environments
}

\author{
KT Paynter \\ JD Goodwin \\ ME Chen \\ NJ Ward \\ MW Sherman
}

See next page for additional authors

Follow this and additional works at: https://scholarworks.wm.edu/vimsarticles

Part of the Marine Biology Commons

\section{Recommended Citation}

Paynter, KT; Goodwin, JD; Chen, ME; Ward, NJ; Sherman, MW; Meritt, DW; and Allen, Standish K., "Crassostrea Ariakensis In Chesapeake Bay: Growth, Disease And Mortality In Shallow Subtidal Environments" (2008). VIMS Articles. 434.

https://scholarworks.wm.edu/vimsarticles/434

This Article is brought to you for free and open access by the Virginia Institute of Marine Science at W\&M ScholarWorks. It has been accepted for inclusion in VIMS Articles by an authorized administrator of W\&M ScholarWorks. For more information, please contact scholarworks@wm.edu. 


\section{Authors}

KT Paynter, JD Goodwin, ME Chen, NJ Ward, MW Sherman, DW Meritt, and Standish K. Allen 


\title{
CRASSOSTREA ARIAKENSIS IN CHESAPEAKE BAY: GROWTH, DISEASE AND MORTALITY IN SHALLOW SUBTIDAL ENVIRONMENTS
}

\author{
KENNEDY T. PAYNTER, ${ }^{1,2 *}$ JACOB D. GOODWIN, ${ }^{1}$ MARCY E. CHEN, ${ }^{1}$ NANCY J. WARD, ${ }^{1}$ \\ MARK W. SHERMAN, ${ }^{1}$ DONALD W. MERITT ${ }^{3}$ AND STANDISH K. ALLEN ${ }^{4}$ \\ ${ }^{1}$ Department of Biology, University of Maryland, College Park, Maryland 20742; ${ }^{2}$ Chesapeake \\ Biological Laboratory, University of Maryland Center for Environmental Science, Solomons, \\ Maryland 20688; ${ }^{3}$ Horn Point Laboratory, University of Maryland Center for Environmental Science, \\ Cambridge, Maryland 21613; ${ }^{4}$ Virginia Institute of Marine Sciences, College of William and \\ Mary, Gloucester Point, Virginia 23062
}

\begin{abstract}
In April 2004, triploid native (Crassostrea virginica) and nonnative (Crassostrea ariakensis) oysters were deployed in cages at four sites along a salinity gradient in Chesapeake Bay. In Maryland, the lowest salinity site was located in the Severn River and two low to mid-salinity sites were located in the Choptank and Patuxent Rivers. The highest salinity site was located in the York River in Virginia. Growth, disease acquisition, and mortality were measured in the deployed oysters through August 2006. Although ANOVA revealed that the nonnative oysters were significantly larger at the end of the experiment than the native oysters at all sites, the differences were much greater at the Virginia site $(59 \mathrm{~mm})$ than in Maryland waters $(9-23 \mathrm{~mm})$. With the exception of $C$. ariakensis in the Severn River, Perkinsus marinus infected both species at all sites. Prevalences and weighted prevalences in both species remained relatively low throughout the experiment, but native oysters consistently acquired higher prevalences and weighted prevalences than $C$. ariakensis by August 2006. With the exception of several mortality-inducing events including winter freezing and hypoxic exposure, mortality was generally low in both species. No disease-related mortality was suspected in either species given the low weighted prevalences observed. In the York River, where a substantial natural spatfall occurred in 2004, more native spat were found on C. ariakensis than on C. virginica. To our knowledge, this is the first comparison of triploid $C$. ariakensis to triploid $C$. virginica conducted in the field. Because we did not observe substantial disease-related mortality, it is too soon to draw conclusions regarding the disease tolerance of $C$. ariakensis in the field or its viability as a replacement for the native species.
\end{abstract}

KEY WORDS: Suminoe oyster, Crassostrea ariakensis, Crassostrea virginica, oyster, Chesapeake, growth, disease, mortality

\section{INTRODUCTION}

In recent years, Perkinsus marinus and Haplosporidium nelsoni, two protozoan parasites, have contributed to the dramatic decline in populations of the eastern oyster, Crassostrea virginica (Gmelin, 1791), in Chesapeake Bay and hindered restoration efforts in many areas. Introduction of the Suminoe oyster, Crassostrea ariakensis (Fujita, 1913), has been proposed as a means of rehabilitating the oyster industry and restoring oyster reef habitats in Chesapeake Bay. Previous studies have indicated that $C$. ariakensis had higher growth rates and lower parasite-related mortality than $C$. virginica (Calvo et al. 2001). Experiments by Calvo et al. (2001), designed to assess the potential use of triploid $C$. ariakensis as an aquaculture species, were conducted in floating racks at sites in Virginia and used populations of $C$. ariakensis and $C$. virginica that differed in disease history, initial rearing environment, and ploidy. In that study, the $C$. ariakensis were triploid and deployed directly from the hatchery (i.e., not previously infected by $P$. marinus), whereas the $C$. virginica to which they were compared were diploid, older and had acquired $P$. marinus infections in the previous year. These factors likely contributed to the differences in growth and mortality observed between species in that study because triploid oysters have been shown to grow faster than diploids (Allen \& Downing 1986) and that second year infections of $P$. marinus are typically more virulent than first year infections (Paynter \& Burreson 1991).

*Corresponding author. E-mail: paynter@umd.edu
Our goal was to control for these factors and to assess the performance of $C$. ariakensis in shallow subtidal habitats, thereby broadening our understanding of the potential utility of $C$. ariakensis as part of an ecological restoration program aimed at restoring oyster reefs in Chesapeake Bay. We examined growth, disease acquisition, and mortality in side-by-side field grow-out experiments. We used hatchery-produced triploid oysters of both species and deployed them simultaneously in shallow subtidal environments at four sites encompassing an environmental gradient from polyhaline southern to oligohaline northern regions of Chesapeake Bay. We found that after 28 mo, C. ariakensis grew to a larger mean size than C. virginica at all sites. However, the differences in final size were relatively small at the Maryland sites but large at the Virginia site. Because $P$. marinus prevalences in our experimental triploids were relatively low even after a third summer of exposure at the Virginia site, we compared $P$. marinus prevalences in diploid $C$. virginica of similar deployment history at the Virginia site and found much higher prevalences in those oysters.

\section{METHODS}

Triploid juvenile $C$. ariakensis and $C$. virginica were placed in mesh oyster cages and deployed at three sites in Maryland (Severn, Choptank, and Patuxent Rivers) and one site in Virginia (York River). Long-term data from nearby NOAA Chesapeake Bay Program monitoring buoys indicated that these sites should provide a range of salinity exposures from 5-25. The methods used in our study were modeled after those of Calvo et al. (2001) to assure comparable results and 
biosecurity. All deployments were permitted by the Virginia Marine Resource Commission, Maryland Department of Natural Resources and/or Army Corps of Engineers after consultation with the Ad-hoc Exotic Species subcommittee of the Living Resources subcommittee of the Chesapeake Bay Program.

Juvenile $C$. virginica and $C$. ariakensis for these experiments were produced in October, 2003, at the VIMS oyster hatchery by crossing tetraploids of each species produced in 2002 with diploids of the same species (see Guo \& Allen 1994). Diploid $C$. virginica came from local Maryland stocks, whereas diploid $C$. ariakensis came from a North American west coast population. Juveniles of both species were held in flow-through tanks at Cherrystone Aquafarms, Cheriton, VA, until deployed in the field in April 2004. At each site, 800 oysters of each species were split between two replicate subtidal cages resulting in four cages (two of each species) at each site. Experimental units consisted of mesh cages (ADPI, Inc) strapped onto underwater racks that held the cages $\sim 0.25 \mathrm{~m}$ above the bottom. To prevent reductions in growth rate because of overcrowding, additional cages were periodically added to the experiment and oyster populations split evenly between old and new cages.

Sites were visited monthly with the following exceptions: a single sampling period was used for November/December 2004 and no samples were taken in March 2005. To assess disease acquisition, oysters were sampled at each site monthly from May through October of 2004 and also in November/December of 2004, in January, May, July and October of 2005, and in August of 2006 (York site only). All live oysters, boxes, and gapers were counted to assess mortality and a subset of live measured each month to assess growth. For growth measurements, 30-40 oysters were haphazardly selected en masse from each cage and their shell height measured to the nearest $\mathrm{mm}$. During months chosen for disease sampling, 15 of the measured oysters from each of two cages were returned to the laboratory for additional analyses. Oysters not selected for laboratory analyses were returned to their original cage. Boxes were discarded, and gapers were returned to the laboratory for disease analysis.

Our sampling design was not well suited for measuring cumulative mortality because we destructively sampled from the cages over time for disease and ploidy testing. To assess mortality, we calculated a "monthly" percent mortality in each cage rather than a cumulative mortality. Monthly mortality was calculated as total boxes and gapers divided by the total number of oysters in each cage (monthly mortality $=$ [gapers + boxes $] /$ [gapers + boxes + live] $\times 100$ ) between sampling periods. It should be noted that each sampling period was not exactly the same but approximately one month. This approach quantified the percent of oysters that died in each cage, because the last sampling was insensitive to prior sampling removals from the cage and provided accurate insight into oyster deaths during a specific time period.

A three-factor ANOVA $(\alpha=0.05)$ was used to test for effects of species, site, and cage in August 2006 shell heights (JMP software, v. 5.0.1.2, SAS Inc.). Initial analyses showed no effect of cage on shell heights, so a two-factor ANOVA was then conducted pooling individual shell heights from cages within species and within site. The two-factor analysis showed a significant interaction between site and species so 1-factor ANOVA was performed to test differences in final shell height between species at each site. Monthly mortality was analyzed using three-factor ANOVA with site, species, and cage as factors. Cages were shown to have no significant effect on mortality, so a two-factor ANOVA was then performed. The two-factor analysis showed a significant interaction between site and species so 1-factor ANOVA was performed to test differences in monthly mortality between species at each site.

In the laboratory, Perkinsus marinus infection was assessed using the thioglycollate assay after Ray (1954), and infection intensity was scored for each oyster using the following categories and corresponding scores: absent $=0$, very light $=$ 0.5 , light $=1$, moderate $=3$, and heavy $=5$. Weighted prevalence (WP) was then calculated as the average infection intensity for each group of oysters sampled $(n=30)$. Oysters sampled from different cages were pooled for disease analysis. In August 2006, samples were also collected and analyzed from diploid $C$. virginica at the York River that were the same age as our experimental animals and had been reared in cages under similar conditions as part of another research project adjacent to our cages. Because P. marinus infections rates in our experimental animals were lower than we had expected, we sampled the diploids to compare with our triploid results, suggesting whether ploidy might have some affect on $P$. marinus infection rates. The diploids were not part of our experimental deployment and this comparison was made only for qualitative purposes. As is typical for data of this nature, no statistical tests were run on prevalence or weighted prevalence values.

Opportunistic observation in the laboratory of the valves of sacrificed oysters revealed that $C$. ariakensis shells from the York River site appeared to have more natural spat settlement on them than did the native oyster shells. Counts were made of spat on both valves of each species from the York River site. Spat/valve were compared using a simple $t$-test $(\alpha=0.05)$.

\section{RESULTS}

\section{Salinity}

Salinity data from NOAA monitoring buoys near each site showed that the Severn River site was characterized by low salinities during the study period (6-12.9) whereas the Choptank and Patuxent River sites had low to moderate salinities (7.9-12.9 and 8.3-15.5, respectively, see Figure 1). The York River site, adjacent to the Virginia Institute of Marine Science (VIMS), was associated with the highest salinity range (16.5-27; see Fig. 1). Although the salinities were more variable at the York River site, no large or unusual shifts in salinity occurred at any of the sites as a result of extended drought or heavy rainfall during the study. Although the Patuxent site reached a high of 15.5 in October 2005, the Maryland salinities remained within a remarkably small range revolving around 10 during most of the study.

\section{Growth}

As of August 2006, the effects of species, site, and their interaction on August mean shell height were all highly significant. At each site, the mean shell height of $C$. ariakensis was significantly greater than $C$. virginica (Table 1, 1-way ANOVA at each site, $P<0.001$ for all sites; Fig. 2). Tests of the effects of site within species found that shell heights at the York River site were significantly greater than the other three 

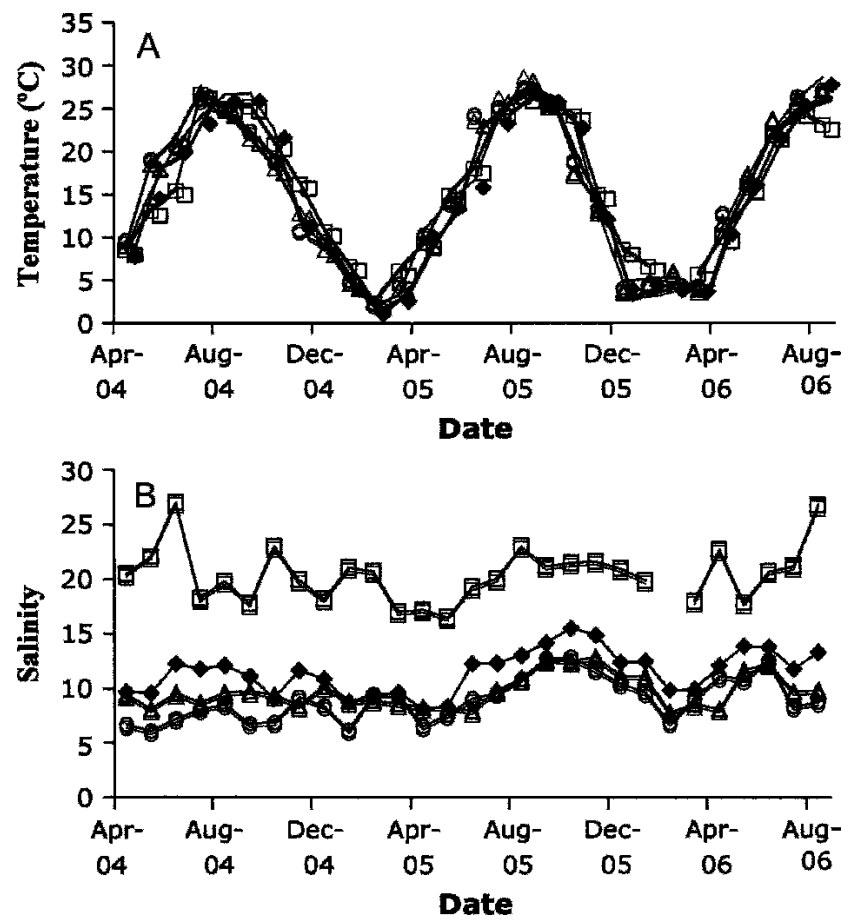

Figure 1. Temperature (A) and salinity (B) data from NOAA monitoring buoys near each site. Buoy LE43 was used for the York site ( $\square$ ), LE1.3 for the Patuxent ( $\diamond)$, ET5.2 for the Choptank $(\Delta)$, and WT7.1 for the Severn $(\bigcirc)$.

sites for both species. Although salinity is unlikely to be the only difference between our sites (see Fig. 1.) and may not be the primary factor driving observed differences in growth, it is clear that $C$. ariakensis growth rates were significantly greater at the Virginia site than at the Maryland sites where $C$. ariakensis reached a mean shell height of nearly $180 \mathrm{~mm}$.

Growth rates of $C$. ariakensis and $C$. virginica within site were nearly identical at all sites for the first four months (Fig. 2). However, during the first fall season (September to December 2004), C. ariakensis continued to grow at summertime rates at all sites except the Patuxent River. After the first fall, increases in shell height over time were remarkably similar between

\section{TABLE 1.}

Final mean (and standard error) shell heights of oysters at all sites. $\mathbf{N}=$ number of oysters measured at final sampling.

Crassostrea ariakensis was significantly larger than $C$. virginica at each site. Crassostrea ariakensis at the York site was significantly larger than oysters of either species raised at any other site.

\begin{tabular}{llccc}
\hline \hline \multicolumn{1}{c}{ River } & \multicolumn{1}{c}{ Species } & $\begin{array}{c}\text { Mean Shell } \\
\text { Height }(\mathbf{m m})\end{array}$ & SE & N \\
\hline \multirow{2}{*}{ Severn } & C. ariakensis & 118.7 & 1.8 & 88 \\
& C. virginica & 97.6 & 1.6 & 36 \\
Choptank & C. ariakensis & 128.1 & 2.5 & 30 \\
& C. virginica & 105.0 & 2.4 & 34 \\
Patuxent & C. ariakensis & 114.5 & 1.7 & 60 \\
& C. virginica & 105.5 & 1.7 & 60 \\
York & C. ariakensis & 174.6 & 2.0 & 60 \\
& C. virginica & 115.2 & 2.0 & 60 \\
\hline
\end{tabular}

species within site at all Maryland sites (i.e., the trend lines are nearly parallel; Fig. 2a to c). At the York River site in Virginia, growth rates of $C$. ariakensis and $C$. virginica differed for the majority of the study (Fig. 2d). After growing through the first summer and part of fall at rates nearly identical to C. virginica, $C$. ariakensis continued to grow until December 2004 when shell height stopped increasing. In contrast, $C$. virginica grew very little between September and December 2004. Shell growth in both species then restarted after March, but $C$. ariakensis growth was more robust. Growth stopped in C. ariakensis during the summer months, and restarted in September 2005, whereas $C$. virginica grew at a slower rate throughout the summer and stopped again in October. Growth in C. ariakensis continued throughout the winter of 2005/2006 until June 2006, when it again slowed through August 2006. During the same period, $C$. virginica grew very slowly, increasing in shell height only $13 \mathrm{~mm}$ between September 2005 and August 2006 compared with the $45 \mathrm{~mm}$ increase observed in C. ariakensis.

\section{Disease}

Prevalences of Perkinsus marinus (Dermo) infections in both species were typical in annual cycle (peaked in October) and in relation to salinity (the highest prevalence in the oysters raised at the highest salinity). First year infections were detected only in native oysters in Virginia ( $\%$ infected $=26.7, \mathrm{WP}=0.23$ ). Second year infections were detected in both species of oysters at all sites except in C. ariakensis at the Severn site (Fig. 3). Although it is difficult to compare disease prevalences statistically (a single sample of 30 oysters is the historic standard for Perkinsiosus diagnosis), Figure 3 shows that $P$. marinus prevalences appear to be similar between oyster species raised at the Choptank and Patuxent sites. However, P. marinus prevalence in $C$. virginica grown in Virginia was almost 4 times that of $C$. ariakensis held at the same site. Weighted prevalences (Fig. 4) showed similar trends with higher infection levels in $C$. virginica at the Virginia site. However, it should be noted that all WP values were quite low (all but one are less than 0.20) relative to levels observed during disease-induced mortality events ( WP $\geq 2.5$ ).

Disease trends in $C$. ariakensis and $C$. virginica at the York River site showed interesting differences (Fig. 4). By the end of the first growing season (October 2004), 26.7\% of the native oysters were infected with $P$. marinus but no parasites were detected in the nonnative oysters. By May of the following year, both species had light infections. By October 2005, 66.7\% of $C$. virginica were infected as compared with only $16.7 \%$ for $C$. ariakensis. Weighted prevalences were also quite different, showing that the native oyster had substantially more intense infections (although, overall, the infections in all oysters remained relatively light). By August, 2006, infection prevalences and weighted prevalences had not changed substantially. However, the diploid $C$. virginica tested that were the same age and held in trays nearby our experimental oysters showed much higher prevalence $(93.1 \%)$ and weighted prevalence $(2.1)$ than either triploid group.

\section{Mortality}

Patterns of mortality were very similar throughout the study but differed between sites and, at times, between species within 

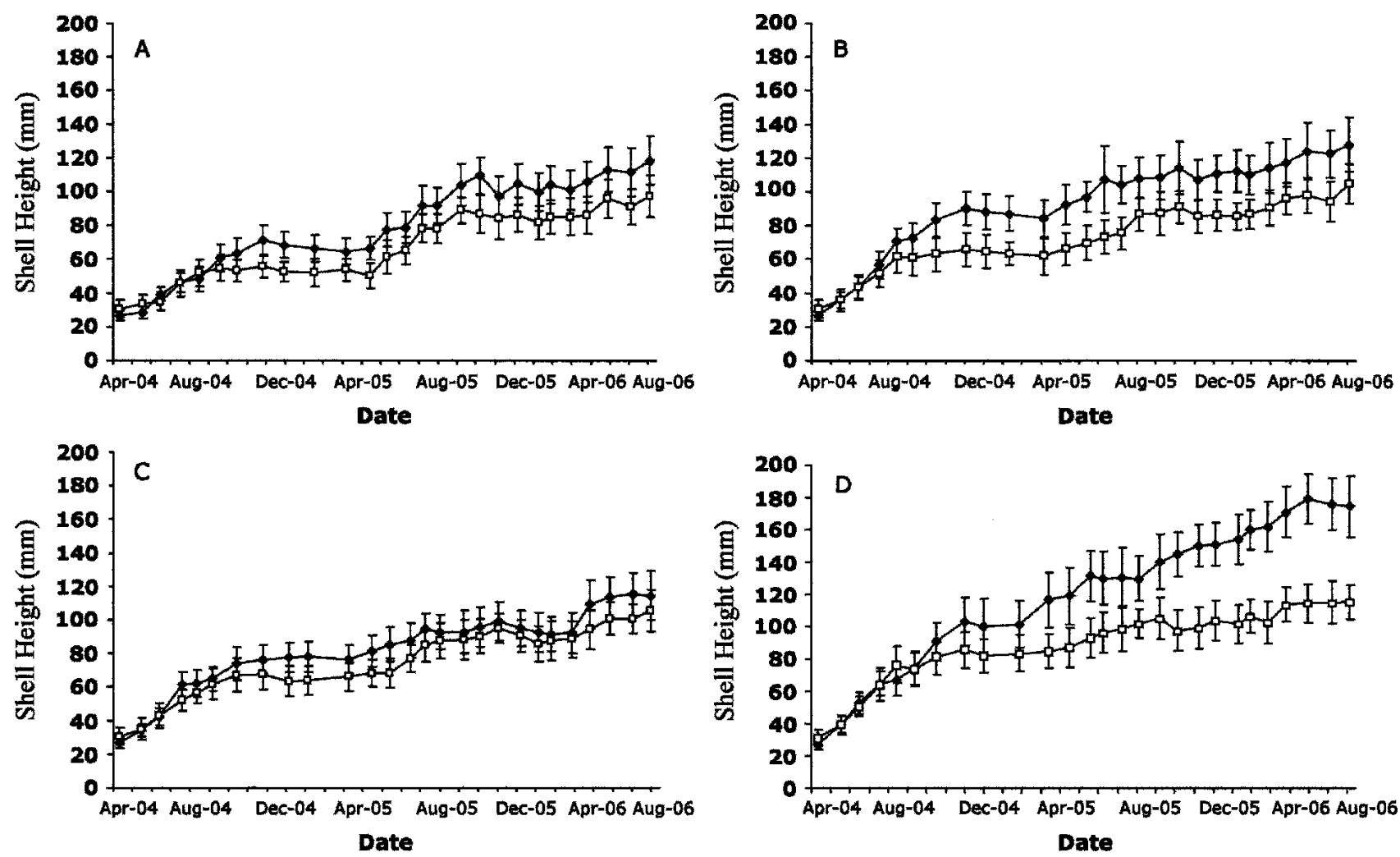

Figure 2. Mean shell height ( \pm SD) of $C$. ariakensis $(\diamond)$ and $C$. virginica $(\square)$ at sites in the Severn (A), Choptank (B), Patuxent (C), and York (D) sites. Except for late Fall 2004 growth in C. ariakensis, increases in shell height were nearly identical over time at the Maryland sites (A to C). However, at the York site, $C$. ariakensis increased shell height throughout the year, whereas $C$. virginica much more slowly. Table 1 shows statistical comparisons of final shell heights.

site (Table 2; Fig. 5). Mean monthly mortality was less than $2 \%$ at all sites in both species. However, we believe several events caused "artifactual" mortality during the course of the experiment. First in the fall of 2004, when oyster cages at the Patuxent site had been transferred into a flow through tank because of heavy seas, water flow was cut off for approximately $72 \mathrm{~h}$ and the tank fouled. After this exposure, approximately $10 \%$ of the C. ariakensis oysters died, whereas less than $2 \%$ of the C. virginica died. In February 2005, a freeze event apparently occurred at the Severn and Choptank sites where an extremely low tide exposed several cages to freezing temperatures. In the Choptank, all oysters in two cages, one of C. ariakensis and one of $C$. virginica were killed. In the Severn, one cage of C. ariakensis experienced over $60 \%$ mortality and one of $C$. virginica over $25 \%$. The $C$. ariakensis cage was more exposed than the $C$. virginica cage and likely resulted in higher mortality of that species at that site. Higher box and gaper counts in the two months subsequent to that event were likely related to it.

Analysis of variance of the monthly mortality data, with freezing outliers removed, showed significant site, species, and interaction effects. In general, mortality was lowest at the low salinity Severn site $(0.67 \pm 0.15$ SEM $)$ and highest at the highest salinity York site $(1.36 \pm 0.16)$, with the Choptank and Patuxent sites in between. Species-specific mortality rates at each site are shown in Table 2. One-factor ANOVA showed that mean monthly mortality was not different between species at the Severn or Choptank sites. However, mean monthly mortality was significantly higher in $C$. ariakensis at the Patuxent site but significantly lower at the York site (Table 2).

A few interesting patterns emerged in the monthly mortality graphs. In the York, mortality in both species appeared to be greater in the summer months - especially $C$. virginica mortalities, which rose over $5 \%$ in $2005 \& 2006$. In the Patuxent, mortalities in both cages of $C$. ariakensis rose in late summer/ fall of 2004 and 2005, whereas $C$. virginica showed no change. We believe these mortalities were in association with temporary transfer of the cages into flow-through enclosed tanks during bad weather. In the Choptank, oysters in both $C$. virginica cages showed a spike in mortality over 10\% in September 2004 and a smaller increase in July 2005. C. ariakensis showed no such mortality at that site and Perkinsus marinus infections in the native oysters did not appear to be heavy enough to cause such mortalities.

\section{Recruitment onto $\mathbf{C}$. ariakensis versus $\mathbf{C}$. virginica}

In summer of 2004, wild C. virginica larvae settled over our study area in the York River but at none of the Maryland sites. Assessment of spat (juvenile oysters) densities conducted in October 2004 found significant differences in the numbers of spat settled on $C$. ariakensis versus $C$. virginica (Mann-Whitney Rank Sum, $P<0.001)$. Almost four times as many spat settled on $C$. ariakensis (4.0 spat/oyster) than on C. virginica (1.1 spat/ oyster) held in side-by-side trays. 

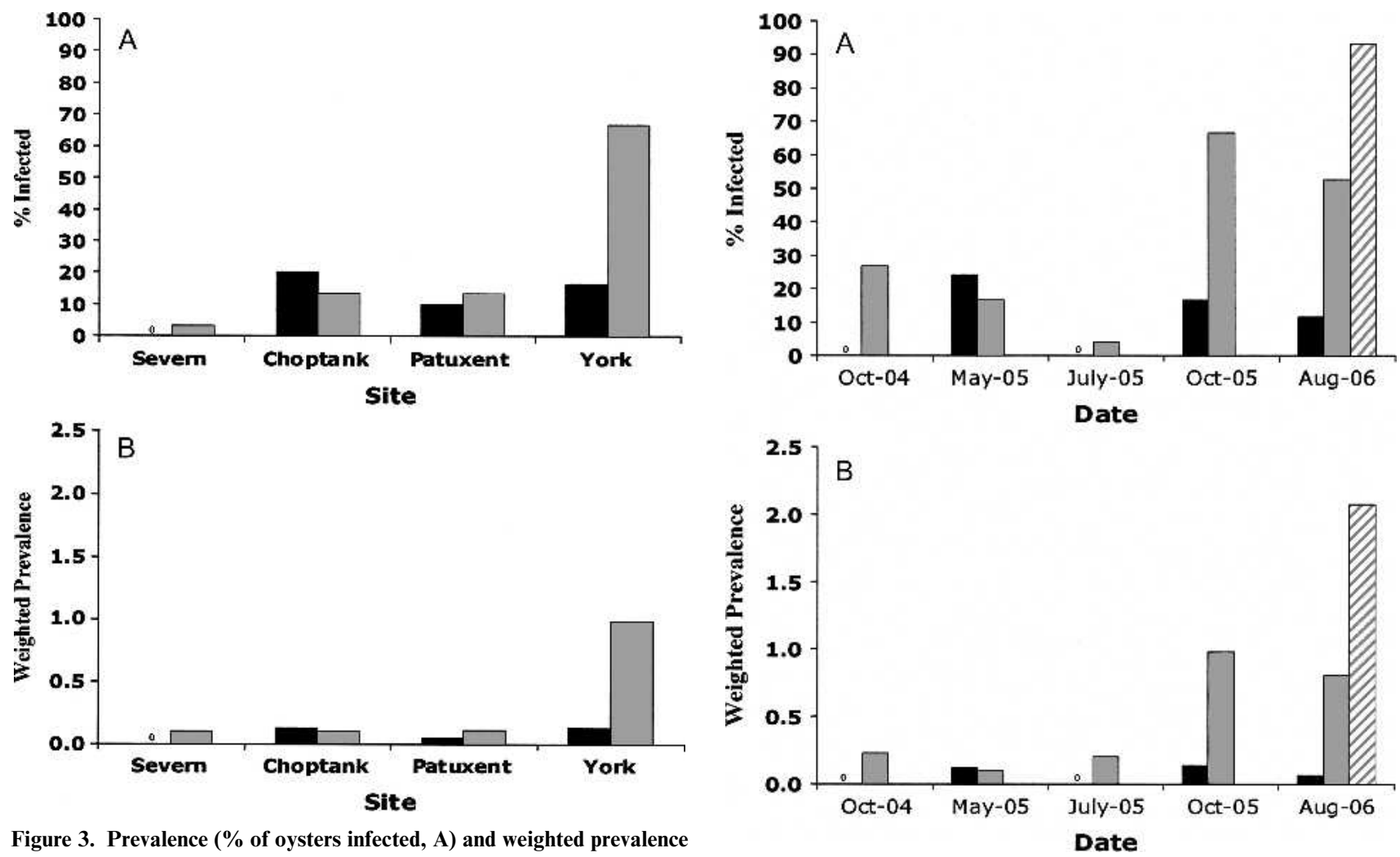

Figure 3. Prevalence (\% of oysters infected, A) and weighted prevalence (B) of $P$. marinus in triploid $C$. ariakensis (black) and triploid $C$. virginica (gray) in October 2005 at all sites. $0=$ All oysters tested were negative for $P$. marinus infection. More native oysters became infected $(>60 \%)$ than nonnatives $(<20 \%)$ at the York site and more heavily infected than $C$. ariakensis.

\section{DISCUSSION}

The suitability of C. ariakensis as an ecological substitute for C. virginica in the Chesapeake Bay depends on the physiological ability of the species to survive and flourish in the Chesapeake ecosystem. This project sought to determine the comparative performance of both species in the field one means of gauging that suitability. One of the main goals was to document the mortality caused in both species by $P$. marinus infections. Typically at the York river site, $P$. marinus will induce mass mortalities in oysters in the second and/or third summer season (Burreson 1991, Paynter \& Burreson 1991). However, $P$. marinus infections in the oysters deployed for this project apparently never reached an intensity level high enough to induce or cause mass mortalities in either species. It is possible that triploidy conveyed some physiological advantage to disease, and thus the experimental oysters were not lethally infected within the expected time frame, although Barber \& Mann (1991) reported no differences in disease susceptibility between triploid and diploid oysters. Despite a lack of diseaseinduced mortality, infection levels were indeed lower in $C$. ariakensis than in the native oyster and one would predict that disease-induced death would come sooner to the natives than $C$. ariakensis. However, we could not demonstrate that, therefore, one of the key questions as to the value or suitability of $C$. ariakensis as an ecological substitute for a diseaseintolerant native oyster remains unanswered by this study. It should be noted that Moss et al. (2006) have shown that

Figure 4. Prevalence (A) and weighted prevalence (B) of $P$. marinus in triploid $C$. ariakensis (black), triploid $C$. virginica (gray), and diploid $C$. virginica (hatched) at the York River site. $0=$ All oysters negative for $\boldsymbol{P}$. marinus infection. Crassostrea ariakensis infections remained relatively low, whereas $C$. virginica infections increased over time to $>60 \%$. Diploid C. virginica oysters with similar deployment history (see text) and tested in August 2006 showed $>\mathbf{9 0} \%$ infection. Weighted prevalences in both species were relatively low considering the three summers of exposure at the York river site. However, $C$. virginica showed higher weighted prevalence than $C$. ariakensis in October 2005 and August 2006. Diploid $C$. virginica showed nearly lethal weighted prevalence.

$C$. ariakensis can acquire lethal infections of $P$. marinus under laboratory conditions and, thus, may not be entirely physiologically resistant to the parasite.

During the study period, C. ariakensis outgrew native oysters at all sites, however, differences in growth rates between the two species were much greater at the higher salinity Virginia site than at the lower salinity Maryland sites. A review of the literature indicates that $C$. ariakensis is generally considered a fast growing oyster. We are unaware of other studies that have specifically addressed differences in growth of $C$. ariakensis as a function of salinity that included sites with low enough salinities to be comparable to those commonly observed on oyster reefs in the Maryland portion of Chesapeake Bay (see Zhou \& Allen 2003 for a review). In Japan, the salinity range for $C$. ariakensis has been reported from 9-30 (Amemiya 1928), whereas in China, multiple reports of optimal ranges cluster around 1030 (Zhou \& Allen 2003). Thus, the three Maryland sites represented suboptimal growth salinities according to the literature, and our results confirm this conclusion. Other studies (Calvo et al. 2001, Grabowski et al. 2004) have shown similar results, although those studies compared diploid native oyster growth to triploid nonnative growth. Triploid oyster growth is 
TABLE 2.

Mean monthly mortality rates of oysters at all sites. Monthly mortality was calculated as (boxes + gapers)/(live + boxes + gapers) $\times 100$ at each sampling period. $N$ represents the number of monthly samples $\times$ number of cages for which monthly mortality estimates were generated.

\begin{tabular}{llccc}
\hline \hline \multirow{2}{*}{ River } & \multicolumn{1}{c}{ Species } & $\begin{array}{c}\text { Mean Monthly } \\
\text { Mortality (\%) }\end{array}$ & SE & N \\
\hline \multirow{2}{*}{ Severn } & C. ariakensis & 0.59 & 0.22 & 48 \\
& C. virginica & 0.76 & 0.22 & 48 \\
Choptank & C. ariakensis & 0.40 & 0.31 & $24 *$ \\
& C. virginica & 1.46 & 0.32 & $24^{*}$ \\
Patuxent & C. ariakensis & $1.23^{* *}$ & 0.22 & 48 \\
& C. virginica & 0.37 & 0.21 & 48 \\
York & C. ariakensis & $0.83^{* * *}$ & 0.22 & 47 \\
& C. virginica & 1.88 & 0.22 & 47 \\
\hline
\end{tabular}

* Oysters in one cage of $C$. ariakensis and one cage of $C$. virginica were killed by freezing in $2 / 2005$.

** C. ariakensis mortality was significantly higher than that of $C$. virginica at the Patuxent site (1-factor ANOVA; $P<0.0078$ ).

*** C. ariakensis suffered significantly less mortality than $C$. virginica at the York site (1-factor ANOVA; $P<0.0024)$. No significant differences in mortality were detected between species at the Severn or Choptank sites (1-factor ANOVA)

sometimes more rapid than conspecific diploid growth (Allen \& Downing 1986, Barber \& Mann 1991). Because the present study compares triploids to triploids, it confirms a true speciesassociated difference in growth rate. Further, the difference in growth rates associated with salinity is remarkable and may indicate that $C$. ariakensis will not grow as much faster than the native oyster in Maryland waters.
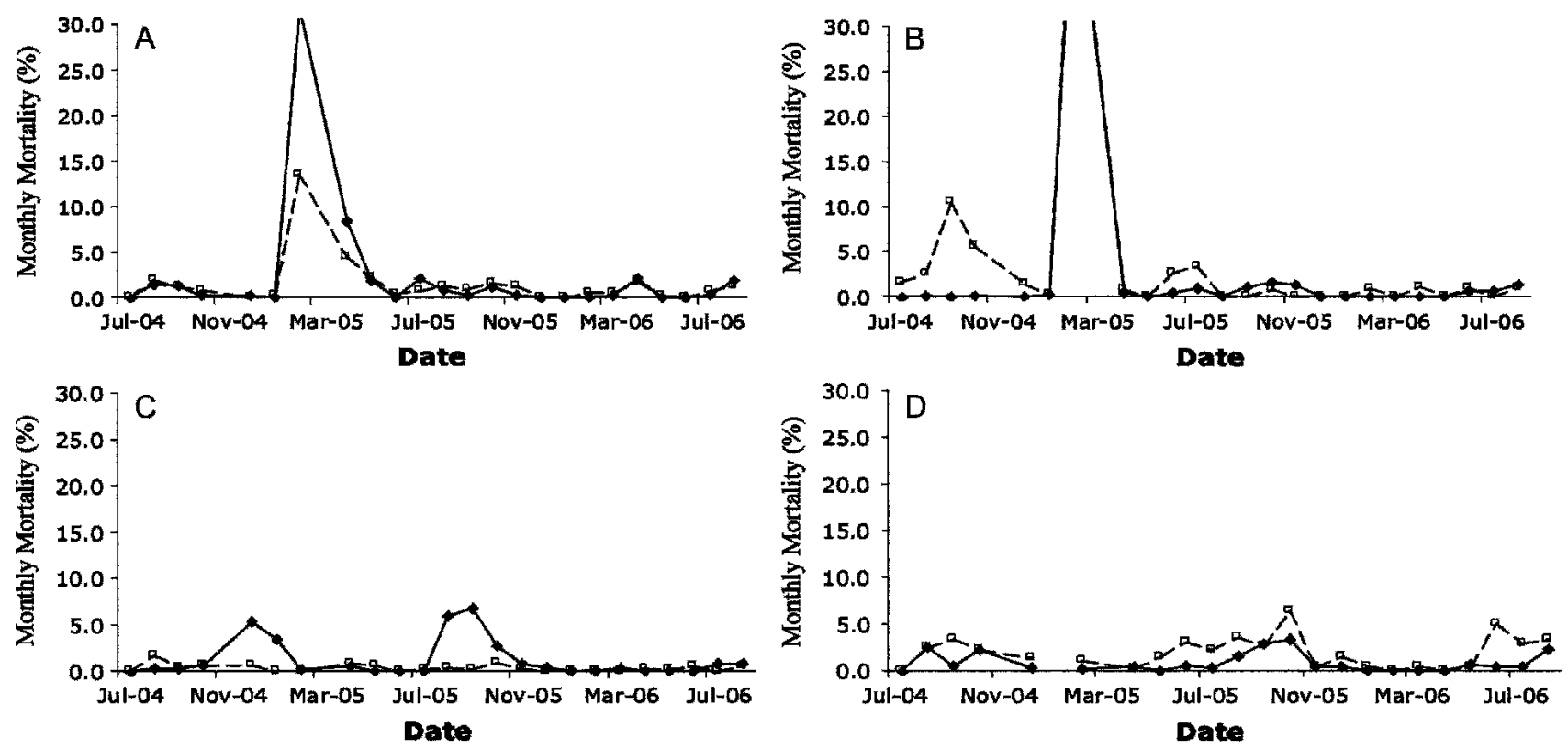

Figure 5. Monthly mortality of $C$. ariakensis $(\diamond)$ and $C$. virginica $(\square)$ at Severn (A), Choptank (B), Patuxent (C), and York (D) sites. Note that the maximum mortality represented on the $\mathrm{Y}$-axis is $30 \%$. Monthly mortality was calculated as (\# boxes + \# gapers)/(\# live + \# boxes + \# gapers) in each of two sampling cages. Boxes and gapers were removed each month. The spikes in mortality in the Severn and Choptank sites were result of a low-tide freeze in one cage of $C$. ariakensis and one cage of $C$. virginica at each site. The two cages frozen at the Choptank site were removed from the study.
In considering whether $C$. ariakensis is a viable replacement for the native species, disease susceptibility may be even more important than growth rate. P. marinus infection rates were low at all sites in both species and did not appear to cause diseaserelated mortalities in either species. However, P. marinus infection has been shown to reduce growth rate in $C$. virginica (Andrews 1965, Paynter \& Burreson, 1991). The reduced growth rates in both summer seasons in $C$. virginica groups with $P$. marinus infections suggest that parasite infection may have contributed to the differential growth rates between species, causing a reduction in growth rate in $C$. virginica. low-tide associated freezing events at the Choptank and Severn sites and apparent anoxic stress at the Patuxent site associated with temporary housing in flow-through tanks. Our suspicion that the differential mortality rates observed in the Patuxent in October 2004 may have been caused by differences in hypoxia/ anoxia tolerance between the two species has been supported by recent work by Harlan (2007) demonstrating that $C$. ariakensis is less tolerant of oxygen stress than $C$. virginica. She found that most $C$. ariakensis held under anoxic conditions died within a few days, whereas most $C$. virginica survived over two weeks. Given the frequency of anoxic and hypoxic events in Chesapeake Bay (Mackiernan 1987, Smith et al. 1992), evaluation of the utility of $C$. ariakensis as a substitute for the native species will need to carefully weigh any advantages in disease resistance against the disadvantages of higher susceptibility to oxygen stress.

Interestingly, in the York River where the only measurable spatfall occurred, significantly more native oyster spat settled did not control for differences in the total surface area available for settlement on the valves of the two species, additional studies will be required to determine whether spat settle at
Mortality rates were low throughout the study except for on $C$. ariakensis than $C$. virginica in 2004. Because our analyses 
higher rates per unit surface area on $C$. ariakensis. That said, the differences in surface area were probably not large, because the mean shell height of $C$. ariakensis at the time of settlement was about $90 \mathrm{~mm}$ and that of $C$. virginica was about $80 \mathrm{~mm}$. This could be an important observation. Because larval settlement is a function of both physical and chemical cues and because hybridization between the two species is unproductive (Allen et al. 1993, Gaffney \& Allen 1993), increased settlement rates of native oyster larvae on nonnative oysters might lead to complex interactions between populations of the two species.

In summary, $C$. ariakensis grew more rapidly than the native oyster at all sites. In addition, parasitic infections were substantially lower in the nonnative oysters, which will likely lead to lower disease-related mortalities, although that was not quantified by this study. The lack of large differences in growth rates in Maryland suggests that disease tolerance might be the most important quality $C$. ariakensis could bring to the upper, less saline Chesapeake Bay. Because no studies, including this one, have quantified differences in disease-related mortality between triploids of the two species and at least one study has shown that $C$. ariakensis can acquire lethal infections of P. marinus (Moss et al. 2006), it is still too soon to draw definitive conclusions regarding the disease tolerance of $C$. ariakensis in the field or its viability as a replacement for the native species.

\section{ACKNOWLEDGMENTS}

The authors thank the many students and staff who helped collect and analyze samples from this study especially Tim Koles and Steve Allen; Karen Hudson for conducting ploidy assays; and the members of the Chesapeake Bay Program Exotic Species Ad-Hoc panel for permitting the work. This study was funded in part by Maryland Sea Grant, the NOAA Chesapeake Bay Program Office, and the University of Maryland.

\section{LITERATURE CITED}

Allen, S. K. \& S. L. Downing. 1986. Performance of triploid Pacific oysters, Crassostrea gigas (Thunberg): I. survival, growth, glycogen content and sexual maturation in yearlings. J. Exp. Mar. Biol. Ecol. 102:197-208.

Allen, S. K., Jr., P. M. Gaffney, J. Scarpa \& D. Bushek. 1993. Inviable hybrids of Crassostrea virginica (Gmelin) with C. rivularis (Gould) and C. gigas (Thunberg). Aquaculture 113:269-289.

Amemiya, I. 1928. Ecological studies of Japanese oysters, with special reference to the salinity of their habitats. J. Coll. Agr. Imp. Univ. Tokyo 9:333-382.

Andrews, J. D. 1965. Infection experiments in nature with Dermocystidium marinum in Chesapeake Bay. Chesapeake Science 6:60-67.

Barber, B. J. \& R. Mann. 1991. Sterile triploid Crassostrea virginica (Gmelin, 1791) grow faster than diploids but are just as susceptible to Perkinsus marinus. J. Shellfish Res. 10:445-450.

Burreson, E. M. 1991. Effects of Perkinsus marinus infection in the eastern oyster, Crassostrea virginica. I. Susceptibility of native and MSX-resistant stocks. J. Shellfish Res. 10:417-423.

Calvo, G. W., M. W. Luckenbach, S. K. Allen, Jr. \& E. M. Burreson. 2001. A comparative field study of Crassostrea ariakensis (Fujita 1913) and Crassostrea virginica (Gmelin 1791) in relation to salinity in Virginia. J. Shellfish Res. 20:221-229.

Gaffney, P. M. \& S. K. Allen, Jr. 1993. Hybridization among Crassostrea species: A review. Aquaculture 116:1-13.

Grabowski, J. H., C. H. Peterson, S. P. Powers, D. Gaskill \& H. C. Summerson. 2004. Growth and survivorship of non-native (Cras- sostrea gigas and Crassostrea ariakensis) versus native eastern oysters (Crassostrea virginica). J. Shellfish Res. 23:781-793.

Guo, X. \& S. K. Allen, Jr. 1994. Viable tetraploids in the Pacific oyster (Crassostrea gigas Thunberg) produced by inhibiting polar body 1 in eggs from triploids. Mol. Mar. Biol. Biotechnol. 3:42-50.

Harlan, N. P. 2007. A comparison of the physiology and biochemistry of the Eastern oyster, Crassostrea virginica, and the Asian oyster, Crassostrea ariakensis. Masters Thesis, University of Maryland, College Park, MD. 70 pp.

Mackiernan, G. B. 1987. Dissolved oxygen in the Chesapeake Bay. College Park, MD: Maryland Sea Grant. 174 pp.

Moss, J. A., E. M. Burreson \& K. S. Reece. 2006. Advanced Perkinsus marinus infections in Crassostrea ariakensis maintained under laboratory conditions. J. Shellfish Res. 25:65-72.

Paynter, K. T. \& E. M. Burreson. 1991. Effects of Perkinsus marinus infection in the eastern oyster, Crassostrea virginica: II. Disease development and impact on growth at different salinities. J. Shellfish Res. 10:425-431.

Ray, S. M. 1954. Biological studies of Dermocystidium marinum, a fungus parasite of oysters. Rice Institute Pamphlet Special Issue, Houston, TX. 114 pp.

Smith, D. E., M. Leffler \& G. Mackiernan. 1992. Oxygen dynamics in the Chesapeake Bay: A synthesis of recent research. College Park, MD: Maryland Sea Grant. 234 pp.

Zhou, M. \& S. K. Allen. 2003. A review of published work on Crassostrea ariakensis. J. Shellfish Res. 22:1-20. 